\title{
Buginese Culture Value System Scale for Entrepreneur and Its Transforming Local Values to a Psychometric Scale
}

\author{
Muhammad Tamar \\ Universitas Hasanuddin \\ Makassar, Indonesia
}

\author{
Hillman Wirawan \\ Universitas Hasanuddin \\ Makassar, Indonesia
}

\author{
Sulasmi Sudirman \\ Universitas Hasanuddin \\ Makassar, Indonesia
}

\begin{abstract}
This study aims at reporting the construction processes and psychometric properties of the Buginese Culture Value System Scale for Entrepreneur (BVSS-E). A number of previous studies found the significant effect of culture and local values in shaping entrepreneurial behavior and entrepreneurship success in Asia, America and Europe. This study initiated a new approach to the entrepreneurship studies by constructing the BVSS-E. This scale was constructed based on seven Buginese's core values. The initial 44-item BVSS-E scale was administered to 300 participants (230 returned the scale). The reliability test yielded .75 Cronbach's alpha. The factor analysis also confirmed the seven-factor model with a good fit. Future studies should provide more evidence regarding the validity and reliability of the scale in different population.
\end{abstract}

\section{Keywords - buginese culture; entrepreneur; local values}

\section{INTRODUCTION}

Local culture values and context shape important roles in determining entrepreneurship and local sectors [1]. The values of local culture bring significant effect to the successful entrepreneurship in one country. Moreover, national culture greatly determines entrepreneurial behaviors [2]. This suggests that local cultures and values should be considered as important factors in developing entrepreneurship in one country.

Aoyama has started an initial study to investigate the effect of local culture in Japan and its effect of national and regional entrepreneurship. This study brought a new approach to understanding the importance of local values [1]. Likewise, This idea was also confirmed by Freytag \& Thurik, where they found that cultural values played distinct roles in entrepreneurship other than economic variables [4]. The culture and values within the cultures determine the successful entrepreneurial behavior and entrepreneurship in one country.

However, there is a discrepancy between the importance of local culture and the measure of culture value system. Moreover, the next step of science and practice should tailor local values and entrepreneurship by providing a valid and reliable measure. It is necessary to provide a measure with robust psychometric properties. For this reason, this study purported to construct a culture value measure in local context. One of major local culture in Indonesia (e.g., Bugis or Buginese in English) served as an example of this practice.

Siri' and Pesse were two core values in Bugisnese culture, this had been used by Tamar as a starting point to assessed the work ethic of Buginese society [5], associated with the core values of Buginese culture that covers 5 values [6], namely: (a) Honesty (lempu ), (b) educated (acca), (c) appropriateness (asitinajang), (d) strength (getteng), and (e) Effort (akkareso). Tamar \& Tamar et al. constructed and designed the inter-correlation of each value to the Bugisnese core values (i.e., Siri and Pesse') [5], [7], which is described as follows:

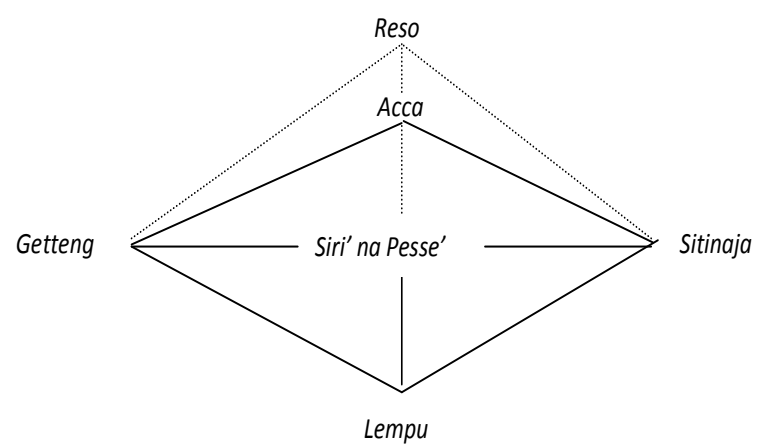

Fig. 1. Buginese Cultural Value System Configuration in the Establishment of the Working Ethos

1) Siri' and Pesse' are the core culture of the Buginese.

a) Siri', in terms of Psychology is individual value which also associated with self-esteem, self-respect, and indignity.

b) Pesse' has closest translation to the value of solidarity or brotherhood in society.

2) Getteng means decisive, stand fast, resilient, and resistant to temptation.

3) Sitinaja means propriety in thought and action, it contained wise meaning, prudent, and fair (equity).

4) Lempu means being honest, compliance.

5) Acca means smart, clever, scholarly, and creative. 
6) Reso means effort, ways and means, and effort in achieving a goal.

These seven values are well-known values among Buginese people and they have passed through generations. They have guided many rules and manners in the Buginese society and have been part of national spirits. Constructing Buginese Culture Value System Scale for Entrepreneur (BVSS-E) is a new step toward understanding local values and their roles in entrepreneurial behavior.

\section{RESERCH METHOD}

\section{A. Participants}

Participants were recruited from small and medium scale enterprises, where all the participants were Buginese entrepreneurs in South Sulawesi. This study used random sampling technique with a number of inclusion criteria; 1) first the participants must affiliate with Buginese culture; 2) running a company in agribusiness sector with a) minimum 5 years operation, b) privately owned, c) run by at least one fulltime employee, and c) minimum annual profit of IDR 10 million to IDR 2 billion (USD 1 = IDR 13.000). There were 300 participants recruited, but only 230 returned the scale.

\section{B. Procedure}

The scale construction followed systematic guidelines from various sources and examples of scale development from a number of sources [8]-[11]. The initial scale construction was started with item generation. Then, experts from the area of Psychology, Social and Business examined each item for content adequacy and validity. Items that did not survive the experts' judgment then dropped.

The initial BCVSS-E was administered to 300 participants. There were $230(76.66 \%)$ returned the scale and 20 participants returned the scale with incomplete responses. As a result, this study only analyzed the data from the $210(70 \%)$ participants (180 males, 30 females). The number of participants were adequate for reliability test and factor analysis [12]. Out of 230, only 24 participants who had college degree, 17 did not complete elementary school, and most participants $(76,33 \%)$ completed high school. Among these participants, $78(37 \%)$ had involved in entrepreneurship for at least 11 years, $56(27 \%)$ possessed more than 6 years business experience, and $20(10 \%)$ had nearly 30 years business experience.

\section{RESULTS AND DISCUSSION}

The BCVS-E was constructed based on Tamar, Tamar et al. early studies on entrepreneurship [5], [7]. Developed the seven core values of Bugis people; Siri', Pesse, Sitinaja, Lempu, Acca, Getteng, and Reso. Utilizing those values, this study started an important step in developing a culture-related instrument to measure value of entrepreneurship. The BCVS$\mathrm{E}$ is a 44-item Likert-type scale ranges from 1 (strongly disagree) to 5 (strongly agree). Two important psychometric properties of the scale as follows:

\section{A. Factor Analysis}

This study performed Confirm tory Factor Analysis (CFA) using Lisrel .10. There were seven factors included in the analysis (see Table 1).

TABLE I. RESULTS OF CONFIRMATORY FACTOR ANALYSIS

\begin{tabular}{|c|c|c|c|c|c|c|}
\hline 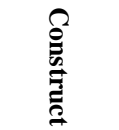 & 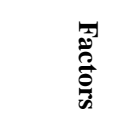 & : & R2 & $\chi^{2}$ & 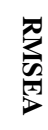 & GFI \\
\hline $\begin{array}{l}\text { Buginese } \\
\text { Culture } \\
\text { Value } \\
\text { System } \\
\text { for } \\
\text { Entrepre } \\
\text { neur }\end{array}$ & $\begin{array}{l}\text { 1. Siri } \\
\text { 2. Pesse } \\
\text { 3.Sitinaja } \\
\text { 4. Lempu } \\
\text { 5. Acca } \\
\text { 6.Getteng } \\
\text { 7. Reso }\end{array}$ & $\begin{array}{l}0.89 \\
0.93 \\
0.88 \\
0.93 \\
0.93 \\
0.91 \\
0.20\end{array}$ & $\begin{array}{l}0.78 \\
0.87 \\
0.78 \\
0.86 \\
0.86 \\
0.83 \\
0.04\end{array}$ & $16.17^{*}$ & .06 & 0.95 \\
\hline
\end{tabular}

Note: $\mathrm{N}=230, * \mathrm{p}<.05, \chi 2=$ Chi Square, REMSA (Root Error Mean Square Approximation), GFI= Good Fit Index

Confirmatory Factor Analysis (CFA) yielded seven factors with REMSA (Root Error Mean Square Approximation) smaller than .05 and GFI (Good Fit Index) .95. Together all these results indicated that the data confirmed the seven-factor model. Say it differently, the BCVS-E yielded seven factors and all these factors measured the same construct (i.e., BCVSE).

\section{B. Reliability}

This study employed reliability test with inter-item correlation technique. As the results, the scale showed .75 Cronbach's alpha. The reliability coefficient was adequate for research purpose. In other words, the BCVS-E had an appropriate reliability coefficient. The coefficient could be improved if the items that had inter-item correlation were dropped. However, maintaining the 44-item BCVS-E still generated an adequate reliability coefficient.

The results showed that using the seven values from Buginese culture produced a valid and reliable measure. This finding is in line with previous studies where culture values determined entrepreneurial behaviors and entrepreneurship success in one country [1], [4]. Albeit the results yielded consistent idea with the previous findings, further investigation is necessary. Future study should provide more information regarding the psychometric properties of the BCVS-E.

\section{CONCLUSION}

In the last few decades, many practitioners and scientists focused their attention to the non-economical factors of the entrepreneurship success. They later found the enormous effect of culture and values within the culture as antecedents of entrepreneurial behavior. Constructing the 44-item BCVS-E brought an initial step toward linking culture, values, and entrepreneurial behavior. Future study should provide more psychometric properties to the scale. 


\section{References}

[1] Y. Aoyama, 'Entrepreneurship and Regional Culture: The Case Entrepreneurship and Regional Culture: The Case of Hamamatsu and Kyoto, Japan', Reg. Stud., vol. 43, no. 3, pp. 495-512, 2009.

[2] E. Autio, S. Pathak, and K. Wennberg, 'Consequences of cultural practices for entrepreneurial behaviors', J. Int. Bus. Stud., no. 44, pp. 334-362, 2013.

[3] A. Freytag and R. Thurik, 'Entrepreneurship and its determinants in a cross-country setting', J. Evol. Econ., vol. 17, pp. 117-131, 2007.

[4] A. Freytag and R. Thurik, 'Entrepreneurship and its determinants in a cross-country setting', pp. 117-131, 2007.

[5] M. Tamar, Pola pemaknaan etos kerja dalam sistem nilai budaya dan implikasinya terhadap kehidupan masyarakat Bugis: laporan kegiatan. Lembaga Penelitian, Universitas Hasanuddin, 2000.

[6] A. R. Rahim, Nilai-nilai utama kebudayaan Bugis. Lembaga Penerbitan Universitas Hasanuddin, 1985.

[7] M. Tamar, N. Rahman, and M. Lampe, Model pengembangan sikap kewirausahaan berbasis budaya lokal: studi terhadap etos kerja pada sistem nilai budaya Bugis dalam pembinaan sikap kewirausahaan generasi muda di Sulawesi Selatan: laporan penelitian. Fakultas Ilmu Sosial dan Ilmu Politik, Universitas Hasanuddin, 2005.

[8] T. . R. Hinkin, J. . B. Tracey, and C. A. Enz, 'Scale construction: Developing reliable and valid measurement instruments', J. Hosp. Tour. Res., vol. 21, no. 1, pp. 100-120, 1997.

[9] S. Warsini, P. Buettner, J. Mills, C. West, and K. Usher, 'Psychometric evaluation of the Indonesian version of the Impact of Event ScaleRevised', J. Psychiatr. Ment. Health Nurs., vol. 22, no. 4, pp. 251-259, 2015.

[10] W. Yang and I. Cooperation, 'Applying Content Validity Coefficient and Homogeneity Reliability Coefficient to Investigate the Experiential Marketing Scale for Leisure Farms', 2006.

[11] H. A. Witemeyer, 'Employee Engagement Construct and Instrument Validation', ProQuest Diss. Theses, vol. E.D.B., 2013.

[12] J. C. F. de Winter, D. Dodou, and P. A. Wieringa, 'Exploratory Factor Analysis With Small Sample Sizes With Small Sample Sizes', Multivariate Behav. Res., vol. 44, no. April, pp. 147-181, 2009. 